\title{
Isolation and Taxonomic Significance of Bacteriophages for Non-proteolytic Clostridium botulinum
}

\author{
By H. SUGIYAMA AND GRETCHEN J. KING \\ Department of Bacteriology and the Food Research Institute, \\ University of Wisconsin, Madison, Wisconsin 53706, U.S.A.
}

(Accepted for publication I5 December 1971)

\begin{abstract}
SUMMARY
Bacteriophages, lytic for wild-type strains of Clostridium botulinum and different from the phages that can be induced from these lysogenic cultures, were isolated from bottom sediments of an inland bay and its tributary river. The host ranges indicated seven phages, in three morphological groups: three were tailless phages, three had hexagonal head and sheathless flexible tail, and one had a sheathed tail. The hosts were restricted to non-proteolytic $C$. botulinum strains producing type B, $\mathrm{E}$, or $\mathrm{F}$ toxin and to a few of the non-toxigenic clostridia which resemble $C$. botulinum type $\mathrm{E}$. None of the phages was active on proteolytic $C$. botulinum producing type $\mathrm{A}, \mathrm{B}$, or $\mathrm{F}$ toxin or cultures producing type $\mathrm{C}$ or $\mathrm{D}$ toxin. The host ranges of the phages are considered to be part of the evidence that the $C$. botulinum types, as defined at present, based on the serological specificity of the toxins, obscure the natural relationships among the strains of the species.
\end{abstract}

\section{INTRODUCTION}

Clostridium botulinum strains are classified as types which are determined by the serological specificity of the neurotoxin (Dolman, \& Murakami, 196I). Apparently all strains of the six types are lysogenic since bacteriophages have been induced in every culture treated with mitomycin C or ultraviolet light (Inoue \& Iida, I968; Eklund, Poysky \& Boatman, I969). However, none of the induced phages is active on wild-type C. botulinum.

Clostridium botulinum type $\mathrm{E}$ is present in high concentrations in the Green Bay portion of Lake Michigan but it is seldom demonstrable in the Fox River, the principal tributary. The river specimens contain a factor(s) which inhibits toxin formation during the enrichment culturing used to detect the organism (Bott, Johnson, Foster \& Sugiyama, 1968).

Bacteriophages virulent for wild-type Clostridium botulinum were found during experiments concerned with the identification of the inhibitor(s). Such phages have not been reported previously and their host ranges among the different $C$. botulinum types are of interest.

\section{METHODS}

Cultures. The strains used are listed in Table I with their geographic origin when such is known. The type E-related cultures are non-proteolytic clostridia producing the "pearly iridescence' developed by type $\mathrm{E}$ on egg yolk agar but are distinctive in not producing toxin. Some are type $\mathrm{E}$ by all other criteria although a few produce a bacteriocin, boticin $\mathrm{E}$ (Kautter, Harmon, Lynt \& Lilly, 1966; Anastasio, Soucheck \& Sugiyama, 1971); others differ in the fermentation of one to three sugars.

Media and cultivation. TPGY was (w/v) $5 \%$ trypticase (BBL, Division of BioQuest, Cockeysville, Maryland, U.S.A.), $0.5 \%$ Bacto-peptone(Difco Laboratory, Detroit, Michigan, 
Table I. Host ranges of bacteriophages active on Clostridium botulinum and type E-related cultures

$\overbrace{\text { Strains }}^{\text {Cultures }}$

Type E (non-proteolytic)

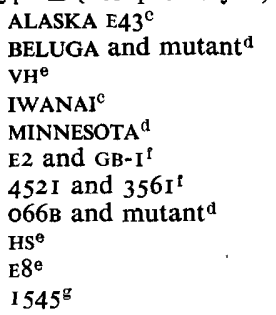

Pacific Ocean, Alaska

Pacific Ocean, Canada

Pacific Ocean, Canada

Japan

Great Lakes, U.S.A.

Great Lakes, U.S.A.

Great Lakes, U.S.A.

Great Lakes, U.S.A.

Atlantic Ocean, Canada

U.S.S.R.

Israel

Type E-related (non-protolytic)

Boticinogenic
s5 $^{\mathrm{d}}, 28-2^{\mathrm{d}}$

$3759^{\mathrm{t}}$

Non-boticinogenic s9

IIRD

15 other strains ${ }^{f}$

Type A (proteolytic)

$3,73,62,109,112,172$,

HALL

Type B

Proteolytic

I I 3, I I 5, I69, 213 ,

6350,7949 , Okra

$2131^{\mathrm{B}}$

Non-proteolytic

$17 \mathrm{~B}^{\mathrm{h}}, 2 \mathrm{~B}^{\mathrm{h}}$

$2129^{\mathrm{g}}$

Type C (non-proteolytic)

$3803(\mathrm{C} \alpha)^{\mathrm{g}}$ and $3804(\mathrm{c} \beta)^{\mathrm{g}}$ $468^{1}$

STOCKHOLM $^{1}$

Type D (non-proteolytic)

$1873^{\mathrm{g}}$

D6-F

Type F

Proteolytic

LANGELAND $^{\mathrm{h}}$

$4257^{\mathrm{B}}$

Non-proteolytic

$83 \mathrm{~F}^{\mathrm{h}}, 202 \mathrm{~F}^{\mathrm{h}}$

$2382^{\mathrm{g}}$
Great Lakes, U.S.A.

Great Lakes, U.S.A.

Great Lakes, U.S.A.

Great Lakes, U.S.A.

Great Lakes, U.S.A.

Unknown (Univ. Wisconsin departmental collection)

Unknown (Univ. Wisconsin departmental collection)

France

Pacific Ocean, U.S.A.

France

\section{Unknown}

Unknown

Sweden

\section{Unknown}

Unknown

Denmark
Argentina
Pacific Ocean, U.S.A.
Scotland
Bacteriophages $^{\mathrm{a}}$

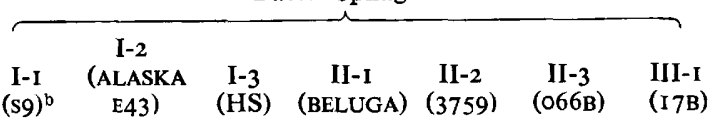

Phage III-I tested on broth cultures; all others on lawns. $+=$ lysis; $-=$ no lysis; NT = not tested.

b ()$=$ Phages isolated with and propagated on indicated cultures; II-2 isolated with culture 3759 but propagated on ALASKA E43 (see text).

c From C. E. Dolman, University of British Columbia, Vancouver, Canada.

a From D. A. Kautter, Food and Drug Administration, Washington, D.C., U.S.A. BELUGA mutant: resistant to boticin; 066B mutant: non-toxigenic.

e From W. P. Segner, Continental Can Company, Chicago, Illinois, U.S.A.

P Isolated in this laboratory.

g From L. V. Holdeman, Anaerobe Laboratory, Virginia Polytechnic Institute, Blacksburg, Virginia, U.S.A.

h From M. W. Eklund, National Marine Fisheries Service, Seattle, Washington, U.S.A.

1 From H. Iida, Hokkaido Institute of Public Health, Sapporo, Japan.

I From E. J. Schantz, Fort Detrick, Maryland, U.S.A.

k Five of I 5 strains tested. 
U.S.A.), $0.4 \%$ glucose, $0 . \mathrm{I} \%$ yeast extract (Difco), $0.2 \%$ sodium thioglycollate (Difco). CMM was cooked meat medium (Difco) reconstituted to contain $0.2 \%$ soluble starch and $0.5 \%$ glucose. LVA was liver veal agar (Difco).

A special meat infusion medium (meat infusion-DTT) was made from the meat byproduct collected during the preparation of beef infusion ( $\mathrm{I} l \mathrm{lb}$ fresh ground beef $/ \mathrm{l}$ of water held overnight at $4^{\circ}$ ). A suspension of meat particles, dried at low heat for storage, in water $\left(\mathrm{I} 5 \mathrm{~g} / 100 \mathrm{ml}\right.$ ) was boiled for $5 \mathrm{~min}$. Fatty material that separated during cooling to $4^{\circ}$ was removed. The infusion was clarified by passing through medium retentive filter paper after mixing in Celite (Johns Manville, New York, N.Y., U.S.A.) and was made up to the original liquid volume with water. To this were added the components of TPGY (with the exceptions of $2.5 \%$ trypticase and sodium thioglycollate) and the $\mathrm{pH}$ adjusted to $7 \cdot 4$. Agar was added as required and the medium was sterilized at $12 \mathrm{I}^{\circ}$ for $20 \mathrm{~min}$. As reducing system and nutrient supplement, a filter-sterilized solution of dithiothreitol, (DTT, $200 \mu \mathrm{g} / \mathrm{ml}$ ), cysteine $(200 \mu \mathrm{g} / \mathrm{ml})$ and glutamine $(200 \mu \mathrm{g} / \mathrm{ml})$ was added after the medium was heated and cooled for use. These concentrations were double those used for plating another oxygen-sensitive Clostridium (Moore, I968).

Spore suspensions were from 4- to 5-day-old TPGY cultures,washed with distilled water. All cultures were incubated at $30^{\circ}$ except type $\mathrm{C}$ strains which were grown at $37^{\circ}$. Plated cultures were incubated in Brewer jars which contained the catalyst of the Torbal anaerobic jar (Scientific Products, Chicago, Illinois, U.S.A.) and which were flushed three times with $\mathbf{H}_{2}$. Extinction at $600 \mathrm{~nm}$ (Spectronic 20; Bausch and Lomb, Rochester, N.Y., U.S.A.) was used to determine turbidity of broth cultures.

Bacterial lawns. Lawns were prepared by the overlay method (Adams, 1959). Soft agar, prepared by mixing I $\mathrm{ml} \mathrm{LVA}$ and $2 \mathrm{ml}$ TPGY, was inoculated immediately before it was poured on to a layer of solidified LVA in Petri plates. Lawns were started with inocula of $10^{6}$ or more spores in 0.1 to $0.3 \mathrm{ml}$ when the cultures sporulated well and permitted preparation of suspension with adequate spore concentrations. Young, vegetative cultures were used to develop lawns of the poorly sporulating strains (Anastasio et al. 1971). However, lawns suitable for phage studies were often not obtained in the LVA-TPGY soft agar, nonproteolytic strains other than type E giving the most difficulty. With these more fastidious cultures, the lawn overlay was $2.5 \mathrm{ml}$ of meat infusion-DTT-0.7\% agar seeded with $0.5 \mathrm{ml}$ of actively growing culture (extinction about 0.4 ) in meat infusion-DTT broth. The base layer medium was the same as the overlay with $\mathrm{I} \cdot 5 \%$ agar. Exposure of organisms to air was minimized by rapid manipulations following the inoculation of overlay agar.

Isolation of phages. Enrichments for phages were $3 \mathrm{~g}$ of bottom sediments from Green Bay and Fox River, similar to those studied in the survey for Clostridium botulinum type $\mathrm{E}$ (Bott et al. 1968) inoculated into $30 \mathrm{ml}$ of CMM and $0.5 \mathrm{ml}$ of a 24 h-old TPGY culture of a strain selected as a possible phage host. After 24 to $48 \mathrm{~h}$ incubation the cultures were centrifuged and the supernatant fluids were passed through a Millipore filter of $0.45 \mu \mathrm{m}$ pores. Further enrichment consisted of adding I ml of the filtrate to a young TPGY culture of the strain used in the original phage enrichment step. The culture was incubated $24 \mathrm{~h}$, centrifuged and filtered.

Nascent lawns of the bacterial strain that had been used for enrichment were spotted with $0.05 \mathrm{ml}$ of the filtrate. If the lawn which developed after incubation showed clear areas where the filtrate had been applied, dilutions of the filtrate were plated by the overlay technique. The phage was purified by replating the extract of an isolated plaque, the sequence being repeated at least three times (Adams, 1959).

Phage stocks were prepared by plating dilutions of the active filtrate with the host strain 
used in the phage isolation. The plate that showed nearly confluent lysis was then extracted with $3 \mathrm{ml}$ of $0.85 \% \mathrm{NaCl}$ (Adams, 1959). The filtered lysates were stored at $4^{\circ}$. The exception was with phage III-I, which has only minimal activity on lawns. Stocks of this phage were lysates of broth cultures.

Electron microscopy. Phage stocks, prepared as described above, and lysogenizing phages, obtained by mitomycin C induction (Inoue \& Iida, I968) of TPGY cultures, were examined. The samples were processed and negatively stained with phosphotungstic acid (Eklund et al. 1969). Examination was with the Zeiss EM 9 A or Hitachi HU I I E electron microscope.

\section{RESULTS}

The first suggestion of phages active on normal Clostridium botulinum cultures was shown by a filtrate of a CMM medium in which a Fox River sediment had been incubated for 4 days. The unheated, organism-free filtrate delayed visible growth by several hours when added to tubes of TPGY inoculated with equal number of spores of the MINNESOTA type $E$ strain, but not if heated to $100^{\circ}$ for $10 \mathrm{~min}$. The culture showing the delayed outgrowth was incubated an additional day and $0.1 \mathrm{ml}$ was transferred to a fresh $10 \mathrm{ml}$ of TPGY. Serial subcultures were made daily until the last transfer was equivalent to a $10^{-14}$ dilution of the culture that had shown the delayed appearance of growth. Although none of the subcultures showed evidence of lysis during incubation, filtrates of both the first and final cultures had $10^{7}$ plaque-forming units (p.f.u.) $/ \mathrm{ml}$ when plated with the MINNESOTA strain.

Multiple phage enrichment cultures from bottom deposits from eight locations in the Fox River and lower Green Bay were made of each specimen by using type E strains (ALASKA E43, MINNESOTA, BELUGA and E2) and type E-related strains (non-boticinogenic s9 and boticinogenic 3759). Eleven purified phage lines were isolated and were tested on lawns of different culture strains. Four different host patterns were obtained. These (phages I-I, I-2, II-I and II-2) are shown in Table I along with those of three other phages that were isolated later by enriching bottom-sediment specimens with the designated culture strains. The three main groups of phages (I, II, III) are based on their general morphology (see below).

Phage II-2 was isolated with culture 3759 but is propagated on culture ALASKA E43 since the former culture produces boticin $\mathrm{E}$ which affects the growth of non-proteolytic cultures (Anastasio et al. 1971). The active agent in these stocks was phage and not bacteriocin according to plaque formation and replication; moreover, in contrast to boticin (Kautter et al. 1966), the activity was destroyed by heating ( $100^{\circ}$ for $5 \mathrm{~min}$ ) but not by treatment with trypsin.

All type E cultures tested were sensitive to at least one of the phages. Comparatively few non-toxigenic, type E-related strains serve as hosts. Enrichments of sediments with type E-related strains did not yield a phage that acted on non-toxigenic strains without acting on a type E strain.

None of the proteolytic Clostridium botulinum was susceptible to the phages. These cultures did not form inactivators of phages; the phages were still active against their type $E$ hosts after incubation at $37^{\circ}$ for 30 min with filtrates prepared from broth cultures of the type A HALL and type B OKRA strains.

Phages I-I, II-2 and II-3, each lytic for one or more type E strains, were active on all three of the non-proteolytic type F strains. In addition, phage II-2 acted on one of the nonproteolytic type B strains. Phage III-I, for which a type E host was not found, was virulent for all three non-proteolytic type B strains but was not active on any of the proteolytic type B strains. However, it did lyse one of the three non-proteolytic type F strains. 

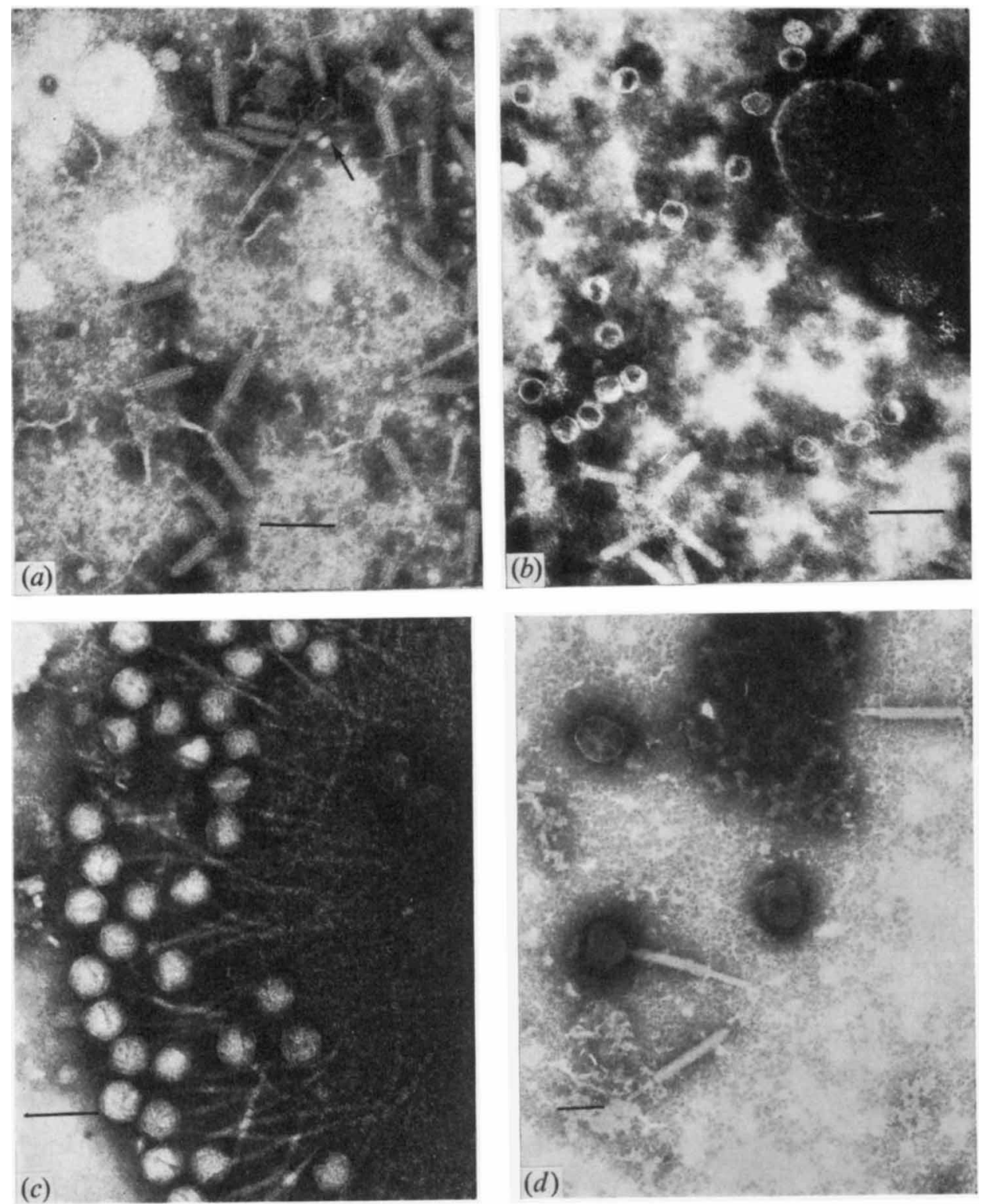

Fig. I. Bacteriophages obtained with type E strain ALASKA E43. Markers equal Ioo nm. (a) Phages induced with mitomycin $\mathrm{C}$; infrequently seen phage at upper right (arrow); $(b)$ phage I-I ; $(c)$ phage II-I ; $(d)$ phage III-I (propagated in culture I7B).

Phage I-I was the most widely distributed; it was recovered from five of eight sediment samples and from the intestinal contents of two of three fish (suckers, Catostomus and Moxostoma) caught in Green Bay. Phage I-2 was recovered from three samples and the remaining phages from one sample each. Phages II-I and II-3 were present in different specimens having I-I.

Electron microscopy showed three general morphological forms among the virulent 


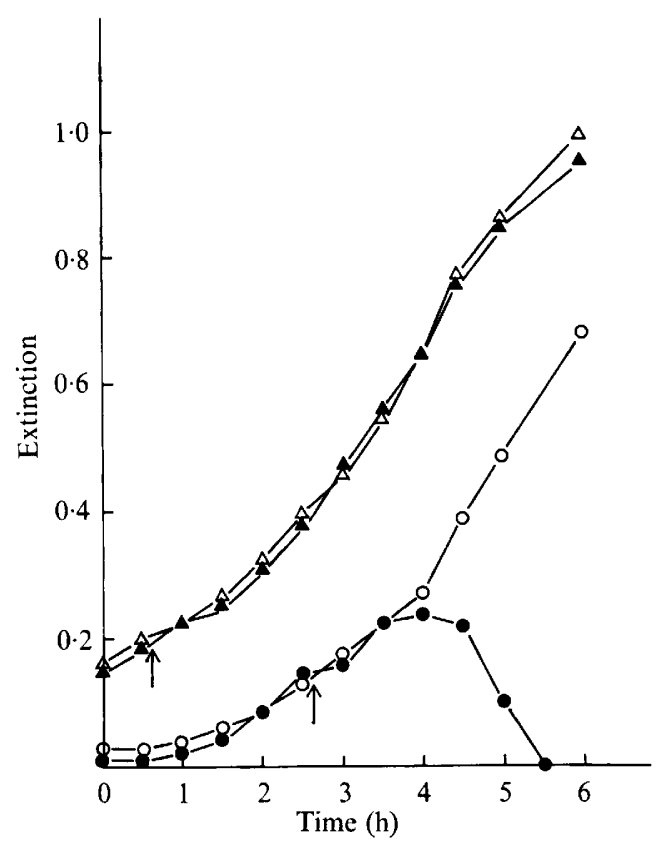

Fig. 2. Changes in extinction (600 nm) of s9 (circles) and ALASKA E43 (triangles) broth cultures incubated with (closed symbols) and without (open symbols) phage I-I. Phage added at arrows.

phages. The phages that could be induced from the wild-type, lysogenic hosts were distinct from the lytic phages. The lysate obtained by inducing the ALASKA E43 strain with mitomycin C had many particles resembling phage tails (Inoue \& Iida, I968; Eklund et al. 1969) and occasionally had a complete phage (Fig. I $a$ ). The lysate that resulted from the action of phage I-I had hexagonal units of $33 \mathrm{~nm}$ diameter (Fig. I $b$ ) which were clearly different from the inducible phages. Phages I-2 and I-3 were morphologically identical to I-I. Phages of this group lacked a tail.

The group II phages differed in dimensions but were similar in having a hexagonal head and flexible, sheathless tail. Their general morphology is illustrated with phage II-I (Fig. I c) which has a head of $58 \mathrm{~nm}$ diameter and a tail of $10 \times 186 \mathrm{~nm}$. The head and tail dimensions of II-2 were $54 \mathrm{~nm}$ and IO $\times$ I54 while those of phage II- 3 were $79 \mathrm{~nm}$ and IO $\times 360 \mathrm{~nm}$. Tails of phages II- 2 and II-3 showed more undulations than those of II-I.

Phage III-I was different from all others in having a sheathed tail (Fig. I $d$ ). The diameter of the head was II $5 \mathrm{~nm}$, the tail length was $318 \mathrm{~nm}$ and the sheath was $22 \times 216 \mathrm{~nm}$.

The host range of III-I was determined by adding I $\mathrm{ml}$ of a phage stock to Io $\mathrm{ml}$ of young broth cultures $\left(E_{600}\right.$ about 0.3$)$ and following culture turbidity during subsequent incubation. During initial isolation only occasional plaques were formed on strain $I 7$ B lawn. The plaques were extracted and spotted on incipient 17B lawns which also developed only a few plaques per plate. Repeated passages on lawns did not increase plaque-forming activity, although the addition of a plaque extract to broth cultures caused subsequent lysis of the cultures. The phage was therefore maintained by passage in broth cultures of $17 \mathrm{~B}$.

The host spectra of the other phages were based on observations made with lawns, since these phages consistently formed clear plaques ( $\mathrm{r}$ to $3 \mathrm{~mm}$ diameter) but did not lyse broth cultures of most host strains. Nevertheless, phage was multiplying in these broth cultures, illustrated by the results with phage I-I. A stock suspension of this phage had $3.5 \times 10^{7}$ p.f.u. $/ \mathrm{ml}$ 
when plated with culture ALASKA E43 and $3.9 \times 10^{7}$ when tested on culture s9. When I ml of the phage stock was added to a young broth culture of each of these two strains, only the s9 culture lysed (Fig. 2). The ALASKA E43 culture that did not show the effect of phage was transferred serially at daily intervals to produce a $10^{-11}$ dilution of the phage stock. A filtrate of this final subculture had $2 \times 10^{7}$ p.f.u./ml when plated with the ALASKA E43 culture, although none of the broth subcultures gave evidence of lysis during their incubation.

Nascent lawns of ALASKA E43, s9 and 202F were spotted with phage I-I and incubated overnight. Isolated colonies were present in the generally clear areas that had resulted from phage activity. The subcultures of a number of these colonies were resistant to phage I-I. When two randomly selected phage-resistant isolates from each of the three phage-culture combinations were treated with mitomycin C ( $\mu \mathrm{g} / \mathrm{ml})$, all lysed. The assumed induced phage in these lysates was enriched by using a young broth culture (wild-type) of host strain s9. The filtrates from these enrichments had a phage whose host range was that of phage I-I.

An identical experiment with phage II-2 and the same three culture strains recovered cultures that were lysogenic for the phage. The subcultures' resistance to the phage that had been used for their isolation resulted therefore from an acquired lysogeny. The new prophages would confer the observed immunity to the homologous phage.

\section{DISCUSSION}

This report presents the first description of bacteriophages that are virulent for wild-type Clostridium botulinum. The previously reported phages of the species are different; they were obtained by induction of the lysogenic cultures and were not lytic for wild-type strains (Inoue \& Iida, I968; Eklund et al. 1969).

Immunity conferred by prophages carried by proteolytic cultures does not explain their resistance to the phages. Such can be inferred because phages induced in these cultures do not act on type $\mathrm{E}$ cultures (unpublished). Moreover, preliminary observations indicate that the phages which are virulent for type $\mathrm{E}$ do not adsorb on to proteolytic Clostridium botulinum.

Phage typing of a taxospecies is based on the strains being more closely related if they are sensitive to the same phage(s) in a set (Stocker, 1955; Meynell, 1964). A close taxonomic relationship is indicated for cultures that are lysogenized by a particular phage since the development of the prophage state requires some homology of the phage and bacterial genomes (Jones \& Sneath, 1970).

The host ranges of the phages and ease of isolating host cultures that have become lysogenized by the phages indicate a close natural relationship of non-proteolytic Clostridium botulinum strains which produce toxins other than type C or D. The same type (B or F) of toxin can be produced by cultures that differ in response to the phages.

Other lines of evidence support the conclusion that the natural relationship of Clostridium botulinum strains is obscured by the present typing that is based on the serology of the toxin. Three metabolic patterns can be discerned among the cultures. Cultures producing type $\mathrm{C}$ or $\mathrm{D}$ toxin have similar metabolism and constitute one group of organisms. The remainder form a proteolytic and non-proteolytic group such that each group is composed of metabolically related strains producing different types of toxin (Smith \& Holdeman, I968).

Comparing the latter two metabolic groups, the non-proteolytic forms are similar in having spores of lower heat resistance than those of the proteolytic group and in their ability to grow and produce toxin at lower temperatures (Schmidt, 1964; Eklund, Poysky \& Wieler, 1967; Eklund, Wieler \& Poysky, 1967). Strains of the non-proteolytic group share 
common somatic antigens which differ from the antigens common among the proteolytic forms (Solomon, Lynt, Kautter \& Lilly, 1971). Binding and competition tests distinguish three classes of DNA: those of types C and D; those of proteolytic strains producing type A, $\mathrm{B}$, or $\mathrm{F}$ toxin; and those of non-proteolytic strains producing type B, E, or F toxin (Lee \& Riemann, I970 $a, b$ ).

Proteolytic strains were called Clostridium parabotulinum in the earlier literature and were distinguished from the non-proteolytic C. botulinum (Bengston, 1924; Gunnison \& Meyer, 1929). These epithets are retained in Bergey's Manual (Breed, Murray \& Smith, 1957) but are not generally used at present (Dolman \& Murakami, I96r). However, the important differences in properties of non-proteolytic and proteolytic strains indicate that wider acceptance of the $C$. botulinum and $C$. parabotulinum terminology is merited.

A problem in the classification of the species is the placement of clostridia that appear to be non-toxigenic forms of Clostridium botulinum. Such forms are found in nature and those related to type $\mathrm{E}$ have been well studied (Kautter et al. 1966; Lee \& Riemann, I970a; Solomon et al. 1971). Moreover, if, as reported for type C (Inoue \& Iida, 1970; Eklund, Poysky, Reed \& Smith, I97I), production of all botulinal toxin types is determined by a specific prophage, the present typing of $C$. botulinum could be based on a phenotypic expression that is not controlled by the bacterium itself.

Research supported by the College of Agricultural and Life Sciences, University of Wisconsin, Madison, and by grant 5-Ror-FD-0009o of the U.S. Public Health Service and contract CPF-69-I with the Food and Drug Administration, Washington, D.C. The excellent technical assistance of Kaoruko Mizutani is acknowledged.

\section{REFERENCES}

ADAms, M. H. (1959). Bacteriophages. New York: Interscience Publishers, Inc.

anastasio, K. L., Soucheck, J. A. \& Sugiyama, H. (I97I). Boticinogeny and actions of the bacteriocin. Journal of Bacteriology 107, 143-I49.

Bengston, I. A. (1924). Studies on organisms concerned as causative factors in botulism. United States Public Health Service, Hygiene and Laboratory Bulletin 136, I-97.

Bott, T. L., Johnson, J., Foster, E. M. \& Sugiyama, H. (1968). Possible origin of the high incidence of Clostridium botulinum type $\mathrm{E}$ in an inland bay (Green Bay of Lake Michigan). Journal of Bacteriology 95 , I $542-1547$.

Breed, R. S., Murray, E. G. D. \& Smith, N. R. (I957). Bergey's Manual of Determinative Bacteriology, 7 th edn. Baltimore, Maryland: Williams \& Wilkins.

Dolman, C. E. \& MuraKami, L. (I96I). Clostridium botulinum type F with recent observations on other types. Journal of Infectious Diseases ro9, 107-128.

Eklund, M. W., Poysky, F. T. \& Boatman, E. S. (I969). Bacteriophages of Clostridium botulinum types $\mathrm{A}, \mathrm{B}, \mathrm{E}$, and $\mathrm{F}$ and nontoxigenic strains resembling type E. Journal of Virology 3, 270-274.

Eklund, M. W., Poysky, F. T., Reed, S. M. \& SMith, C. A. (I97I). Bacteriophage and the toxigenicity of Clostridium botulinum type C. Science, New York 172, 480-482.

Eklund, M. W., Poysky, F. T. \& WIEleR, D. I. (1967). Characteristics of Clostridium botulinum type F isolated from the Pacific coast of the United States. Applied Microbiology I5, I3 I6-I323.

EkLund, M. W., Wieler, D. I. \& PoysKy, F. T. (I967). Outgrowth and toxin production of non-proteolytic type B Clostridium botulinum at $3 \cdot 3$ to $5 \cdot 6$ C. Journal of Bacteriology 93, 1461-1462.

Gunnison, J. B. \& MeYer, K. F. (1929). Cultural study of an international collection of Clostridium botulinum and parabotulinum. Journal of Infectious Diseases 45, 119-134.

INOUE, K. \& IIDA, H. (I968). Bacteriophages of Clostridium botulinum. Journal of Virology 2, 537-540.

INOUE, K. \& IIDA, H. (1970). Conversion of toxigenicity in Clostridium botulinum type C. Japanese Journal of Microbiology 14, 87-89.

Jones, D. \& SNEATH, P. H. A. (1970). Genetic transfer and bacterial taxonomy. Bacteriological Reviews 34, 40-8I. 
KaUtTer, D. A., Harmon, S. M., LyNT, R. K. \& Lilly, T. (1966). Antagonistic effect on Clostridium botulinum type E by organisms resembling it. Applied Microbiology 14, 616-622.

LEE, W. H. \& RIEMANN, H. (1970a). Correlation of toxic and non-toxic strains of Clostridium botulinum by DNA composition and homology. Journal of General Microbiology 6o, 117-123.

LeE, W. H. \& RiemanN, H. (1970 $b$ ). The genetic relatedness of proteolytic Clostridium botulinum strains. Journal of General Microbiology 64, 85-90.

MEYNELL, E. (I964). The significance of bacteriophage in bacterial classification. A review. Journal of General Microbiology 36, 46I-469.

MOORE, W. B. (1968). Solidified media suitable for the cultivation of Clostridium novyi type B. Journal of General Microbiology 53, 415-423.

SCHмidt, C. F. (1964). Spores of C. botulinum: Formation, resistance, germination. In Botulism, Proceedings of a Symposium, pp. 79-82. Edited by K. H. Lewis \& K. Cassel. Public Health Service Publication no. 999-FP-I.

Smith, L. D. S. \& Holdeman, L.V.(1968). The Pathogenic Anaerobic Bacteria. Springfield Illinois: Charles C. Thomas.

Solomon, H. M., Lynt, R. K., Kautter, D. A. \& Lilly, T. (I971). Antigenic relationships among the proteolytic and nonproteolytic strains of Clostridium botulinum. Applied Microbiology 21, 295-299.

STOCKER, B. A. D. (1955). Bacteriophage and bacterial classification. Journal of General Microbiology 12, 375-38r. 